\title{
Morphological and Molecular Characterization of Rhizoctonia solani causing Sheath Blight in Rice
}

\author{
Suryawanshi Padmaja Pralhad $^{1 *}$, P.U. Krishnaraj ${ }^{2}$ and S.K. Prashanthi ${ }^{3}$ \\ ${ }^{1}$ Department of Biotechnology, ${ }^{2}$ Department of Agricultural Microbiology, ${ }^{3}$ Department of \\ Plant Pathology, College of Agriculture, University of Agricultural Sciences, \\ Dharwad - 580005, Karnataka, India \\ *Corresponding author
}

\section{A B S T R A C T}

\section{Keywords}

Sheath blight, Rice, Rhizoctonia solani, Sclerotium, Pathogen, Virulence

Article Info

Accepted:

12 December 2018

Available Online:

10 January 2019

\begin{abstract}
Sheath blight of rice is an economically important pathogen of rice worldwide. The simple methods based on morphological markers can be used to identify the associated pathogens. In the present study, three fungal isolates were studied for morphological and pathological characters. They were fast growing in culture medium with differences in sclerotia formation and exhibited varying degree of virulence on the same cultivar BPT5204, a variety susceptible to sheath blight. The isolate RS4 was found to be highly virulent with $78 \%$ disease incidence. Precise identification of cause of disease based on morphological characters and symptoms induced by Rhizoctonia sp. becomes tedious because of similarity in symptoms. The identification of isolates at genus and species level using molecular markers for genetic differentiation would be an ideal approach. The isolate RS4 showed $99 \%$ homology with $R$. solani AG1-IA based on nucleotide sequence data for ITS 5.8S-rDNA region.
\end{abstract}

\section{Introduction}

Rice is the staple food for more than $60 \%$ of the world's population and the demand is expected to continue to grow as population increases (USCB, 2015). Although India has the largest area under rice cultivation, the productivity is low which has been attributed to several biotic and abiotic stresses (Mohanty and Yamano, 2017). In-depth understanding of the pathogens involved is necessary, for the effective management of plant diseases. The most common and severe diseases in rice are blast, sheath blight and bacterial leaf blight
(Woperies et al., 2009). Sclerotia forming fungi of genus Rhizoctonia and Sclerotium are associated with the sheath blight complex in rice plants (Kimiharu et al., 2004; RamosMolina and Chavarro-Mesa, 2016).

The identification of Rhizoctonia sp. isolates is tedious due to absence of stable morphological and physiological characteristics (Mordue et al., 1989). A report from India indicated some isolates could anastomose with an AG-1 IA tester isolate; however based on isozymes they probably belonged to $R$. oryzae-sativae (Neeraja et al., 
2002). In another study, several Rhizoctonia isolates purified from rice were revealed to be unidentified Rhizoctonia sp., while few were similar to Cerratobasidium oryzae-sativae (Linde et al., 2005). Such findings emphasize the use of molecular markers for studying fungal pathogens of rice sheath disease. Several studies on rice sheath blight have used molecular markers such as RAPD (Guleria $e t$ al., 2007; Susheela, 2012; Lal et al., 2014; Singh et al., 2015), RFLP (Linde et al., 2005), AFLP (Taheri et al., 2007) and ISSR (Guleria et al., 2007; Yugander et al., 2015; Goswami et al., 2017) along with morphological markers. Recently, rDNA-ITS sequencing has been used for identifying variations (RamosMolina and Chavarro-Mesa, 2016; Bintang et al., 2017; Singh et al., 2018).

The current study was aimed at studying morphological and pathological variations in fungus associated with sheath blight complex in rice, and identifying them through sequencing of ITS 5.8S-rDNA region. The findings would help breeders in screening of plant genetic resources and pathologists for evaluation of chemical fungicides and biocontrol agents during development of disease management practices.

\section{Materials and Methods}

\section{Isolation of fungus from sheath blight diseased sample}

The isolation of fungus was done from rice plants (Table 1) showing sheath blight symptoms (Taheri et al., 2007). Samples of rice sheaths were thoroughly washed with running tap water, surface sterilized using 1.5 $\%$ sodium hypochlorite for $1 \mathrm{~min}$ and rinsed three times in sterile distilled water. Small bits containing advancing margin of infection were cut from samples, dried on sterilized filter paper, transferred to water agar plates and incubated at $28{ }^{\circ} \mathrm{C}$. After 2 to 3 days, cultures were examined for the mycelium of fungus and purified on Potato Dextrose Agar (PDA). The pure cultures were maintained on PDA at $4^{\circ} \mathrm{C}$.

\section{Morphological characterization of isolates}

The fungal isolates were subcultured on PDA plates in three replications and incubated at $28^{\circ} \mathrm{C}$ upto 2 weeks. Observation were recorded for each isolate based on mycelial and sclerotial (colour, size, type) morphological characters (Lal et al., 2014; Susheela, 2012).

\section{Pathogenicity test}

Healthy plants of susceptible rice variety, BPT5204 were grown in sterilized soil in pots in greenhouse upto one month. Mycelial discs of approximately $0.5 \mathrm{~cm}$ diameter from 3-dayold fungal cultures grown on PDA medium were inoculated to the sheath of each plant using sterile toothpicks and covered with moist cotton and aluminium foil (Jia et al., 2013). Each pot was covered with a clean polythene cover to generate high humidity. The vertical spread of disease was observed upto 30 days after pathogen inoculation and expressed as Relative Lesion height $(\mathrm{RLH})=$ Lesion length $(\mathrm{cm}) /$ Plant height $(\mathrm{cm})$ (Sharma et al., 1990). The disease incidence percentage (Least virulent: $10-29 \%$; Moderately virulent: $30-49 \%$; Virulent: $50-69 \%$; Highly virulent: $70-90 \%$ ) was used to determine virulence of isolates (Susheela and Reddy, 2013). The statistical analysis of the disease response was based on a completely randomized design for three treatments and 10 pots per treatment.

\section{Molecular identification of isolates}

For each isolate, the mycelium from 3 day old culture was inoculated in $50 \mathrm{ml}$ of potato dextrose broth and incubated in an Erlenmyer 
flask on a rotary shaker at $28^{\circ} \mathrm{C}$. The fungal mycelium was harvested after 5 days and ground to a fine powder in liquid nitrogen using a mortar and pestle. The DNA was extracted from the mycelia powder using the DNeasy Plant Mini DNA extraction kit (Qiagen, Germany) according to the specifications of the manufacturer.

The primer pair ITS1/ITS4 (White et al., 1990) was used for amplification of ITS region of rDNA of the fungal isolates. The PCR program employed for amplification was initial denaturation at $94{ }^{\circ} \mathrm{C}$ for $5 \mathrm{~min}$, followed by 35 cycles of denaturation at $94{ }^{\circ} \mathrm{C}$ for $1 \mathrm{~min}$, annealing at $55{ }^{\circ} \mathrm{C}$ for $1 \mathrm{~min}$ and extension at $72{ }^{\circ} \mathrm{C}$ for $1 \mathrm{~min}$. A final extension was done at $72{ }^{\circ} \mathrm{C}$ for $45 \mathrm{~min}$ to add dATP at $3^{\prime}$ end.

One percent agarose gel was used for separation of DNA fragment and purified using Qiagen Min Elute Gel Extraction kit (Qiagen, Germany) according to manufacturer's instructions. The ligation reaction was set for eluted product with pTZ57R/T vector as described in Ins T/A clone $^{\text {TM }}$ PCR cloning kit (Thermo Scientific, USA). The ligated products were transformed to competent E. coli $\mathrm{DH} 5 \alpha$ cells. The preparation and transformation of competent E. coli $\mathrm{DH} 5 \alpha$ using calcium chloride was done according to the protocol mentioned by Sambrook and Russell (2001). The transformants were identified by blue/white colony assay on Luria-Bertani agar plates containing Ampicillin $(100 \mu \mathrm{g} / \mathrm{ml})$, X-gal $(16 \mathrm{mM})$ and IPTG $(16 \mathrm{mM})$. The alkaline lysis method given by Sambrook and Russell (2001) was used for isolation of plasmid DNA from positive clones. The presence of insert was confirmed by restriction digestion $(\mathrm{BamH}$ I and Xba I).

The positive clones carrying insert in $\mathrm{pTZ57R/T}$ were sequenced using universal
M13 F/R primer (Xcelris Lab Limited, Ahmedabad). The sequences of vector origin were identified using NCBI program VecScreen. The forward and reverse sequences of each isolate were aligned using the BioEdit contig assembly program version 7.2.5 (Hall, 1999). The sequence was submitted to NCBI database for similarity search using BLAST algorithm (Altschul et al., 1990). The contiguous sequences were deposited to GenBank.

\section{Results and Discussion}

Sheath blight complex in rice is a major constraint to rice production. Overwintering and wide host range of Rhizoctonia further makes the disease control a difficult task. The disease diagnosis is an important step before initiation of any management practices.

\section{Morphological characterization}

In present study, three fungal isolates were studied for morphological characters. The observations for mycelia growth and sclerotia were recorded from plates with fungal cultures upto 2 weeks (Fig. 1 and Table 2). All the three fungal isolates covered the entire Petri plate surface of $90 \mathrm{~mm}$ diameter after 4 days of incubation; indicating their fast growing nature. The isolate RS1 had fluffy colony texture and did not form sclerotial bodies. Isolate RS3 formed many round smaller brown to black sclerotia of size $1 \mathrm{~mm}$ scattered within the PDA plates after 7 days of incubation. Isolate RS4 showed formation of few dark brown sasakii type sclerotia of size 2 $-4 \mathrm{~mm}$ after 10 days of incubation.

\section{Test for pathogenicity of different isolates}

The use of polythene covers helped in maintaining high humidity, which allowed high fungal establishment. The early sheath blight symptoms (water soaked spots) were 
observed in BPT5204 after 3 days of pathogen inoculation. All the three isolates exhibited varying degree of virulence (Fig. 2 and Table 3) on BPT5204, a sheath blight susceptible variety. The isolate RS4 was found to be highly virulent with $78 \%$ disease incidence, while RS1 showed only $9.21 \%$ disease incidence. Many workers have reported morphological as well as pathological variations in fungal isolates associated with sheath diseases of rice (Guleria et al., 2007; Singh et al., 2015; Ramos-Molina and Chavarro-Mesa, 2016; Singh et al., 2018). Macro-sized sclerotia forming isolate RS4 was observed to be more virulent than isolate RS3 which formed micro-sized sclerotia; and nonsclerotia forming isolate RS1 was the least virulent. Kumar et al., (2008) and Goswami et al., (2017) have also reported that isolates with macro-sized sclerotia are highly virulent as compared to isolates with micro-sized sclerotia. Non-sclerotia producing isolate showing poor symptom expression in pathogenicity tests was mentioned by Singh $e t$ al., (2018). Ramos-Molina and ChavarroMesa, (2016) reported $R$. solani AG1-IA isolates as more pathogenic than other Rhizoctonia sp. and S. hydrophilum. Similar results were observed in our study, where RS4 was more virulent than RS1 and RS3.

\section{Molecular confirmation of isolates}

Some Sclerotium species are related to the genus Rhizoctonia, which form sclerotia and sterile mycelia with hyphae branching at right angles (Tredway and Burpee, 2001; Xu et al., 2010). Thus, the identification of disease based on morphological markers and symptoms induced by these fungi becomes tedious.

Table.1 The details of fungal isolates used in the study

\begin{tabular}{|l|l|l|}
\hline Isolate ID & $\begin{array}{l}\text { Sample (Rice } \\
\text { variety) }\end{array}$ & Location \\
\hline RS1 & BPT5204 & $\begin{array}{l}\text { Institute of Agri-Biotechnology, } \\
\text { College of Agriculture, Dharwad, Karnataka }\end{array}$ \\
\hline RS3 & BPT5204 & Farmer's field, Gangavathi, Karnataka \\
\hline RS4 & BPT5204 & Agricultural Research Station, Gangavathi, Karnataka \\
\hline
\end{tabular}

Table.2 Cultural and sclerotial characteristics of different R. solani isolates on PDA medium

\begin{tabular}{|l|l|l|l|l|l|l|l|l|}
\hline & \multicolumn{3}{|c|}{ Colony characters } & \multicolumn{5}{c|}{ Sclerotium characters } \\
\hline $\begin{array}{l}\text { Isolate } \\
\text { ID }\end{array}$ & $\begin{array}{l}\text { Mycelial } \\
\text { colour }\end{array}$ & $\begin{array}{l}\text { Growth } \\
\text { pattern }\end{array}$ & $\begin{array}{l}\text { Type of } \\
\text { dispersion }\end{array}$ & $\begin{array}{l}\text { Time } \\
\text { taken for } \\
\text { initiation } \\
\text { of } \\
\text { sclerotia }\end{array}$ & Colour & Position & Size & Number \\
\hline RS1 & $\begin{array}{l}\text { Yellowisn } \\
\text { brown }\end{array}$ & Abundant & Spatial & - & - & - & - & Absent \\
\hline RS3 & $\begin{array}{l}\text { Cream } \\
\text { brown }\end{array}$ & Moderate & Spatial & 4 days & $\begin{array}{l}\text { Brown } \\
\text { to } \\
\text { black }\end{array}$ & $\begin{array}{l}\text { Well } \\
\text { distributed }\end{array}$ & Micro & Excellent \\
\hline RS4 & $\begin{array}{l}\text { White } \\
\text { brown }\end{array}$ & Slight & Spatial & 8 days & $\begin{array}{l}\text { Dark } \\
\text { brown }\end{array}$ & Periphery & Macro & Good \\
\hline
\end{tabular}


Table.3 Disease incidence during fungal inoculation

\begin{tabular}{|l|l|l|l|}
\hline $\begin{array}{l}\text { Pathogen } \\
\text { ID }\end{array}$ & Disease incidence $\mathbf{( \% )}$ & Plant parts affected & Virulence nature \\
\hline RS1 & 12.275 & Sheath & Less virulent \\
\hline RS3 & 46.814 & Sheath, Stem & Moderately virulent \\
\hline RS4 & 90.596 & Sheath, Stem, Leaf & Highly virulent \\
\hline
\end{tabular}

Table.4 Molecular identification of fungus based on rDNA analysis

\begin{tabular}{|l|l|l|l|}
\hline Isolate ID & Contig length & Similarity with & Accession number \\
\hline RS1 & $723 \mathrm{bp}$ & Rhizoctonia solani AG4-HGIII & MK213722 \\
\hline RS3 & $773 \mathrm{bp}$ & Rhizoctonia solani & MK213723 \\
\hline RS4 & $713 \mathrm{bp}$ & Rhizoctonia solani AG1-IA & MK213724 \\
\hline
\end{tabular}

Fig.1 The growth of fungal isolates on PDA medium after 10 days of incubation Legend: 1a: RS1, 1b: RS3, 1c: RS4
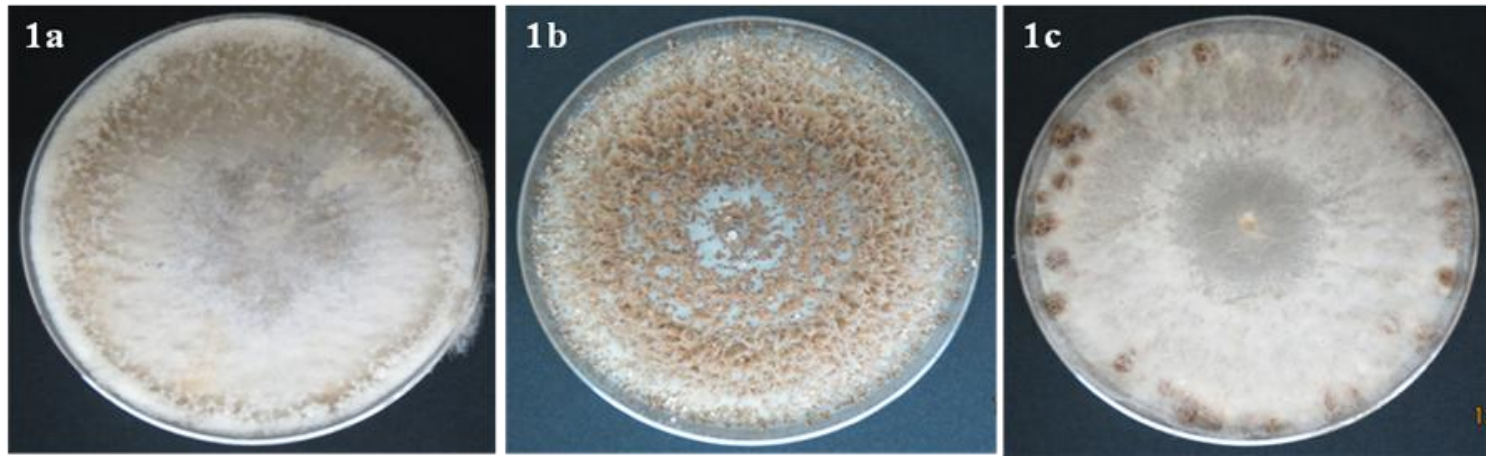

Fig.2 Virulence of fungal isolates observed on BPT5204 plants Legend: 2a: RS1 inoculation, 2b: RS3 inoculation, 2c: RS4 inoculation
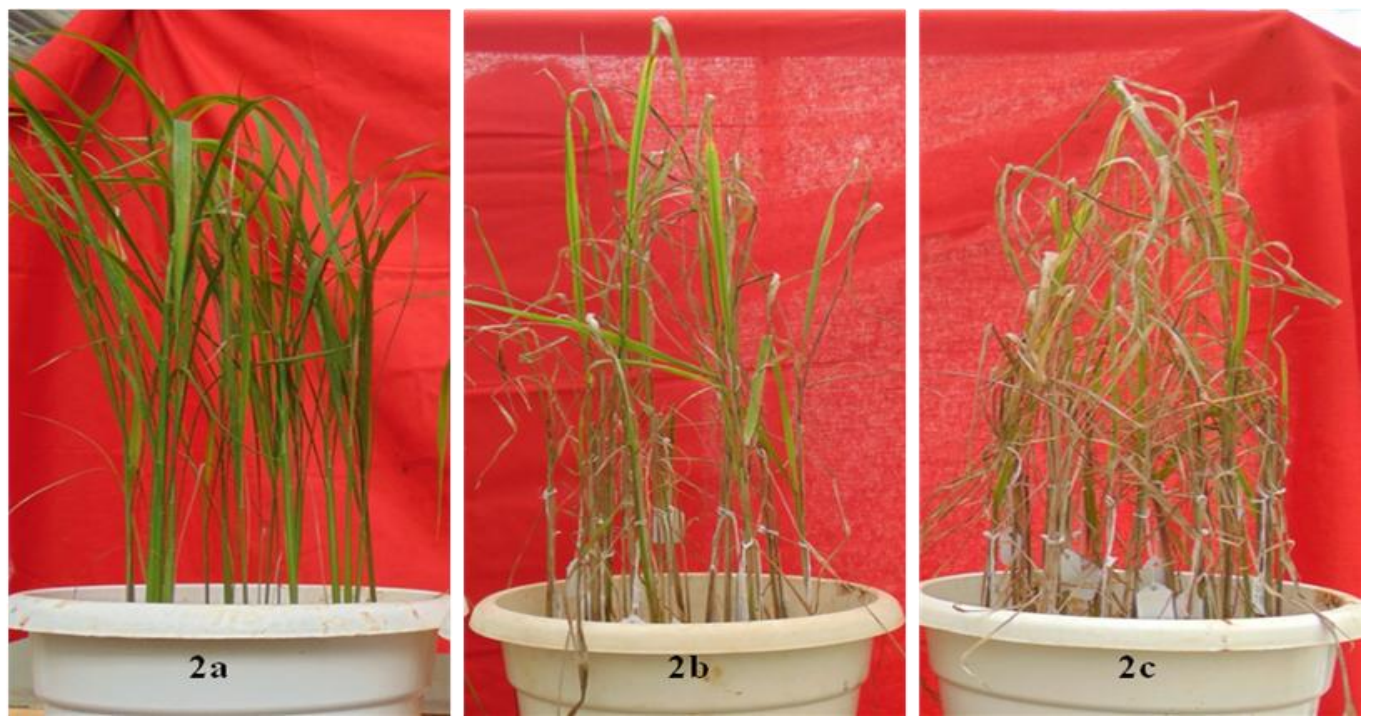
Fig.3 PCR amplification with primer ITS1/ITS4 pair from total genomic DNA of Rhizoctonia isolates

Legend 3: Lane 1: 100bp ladder, Lane 2: RS1, Lane 3: RS3, Lane 4: RS4

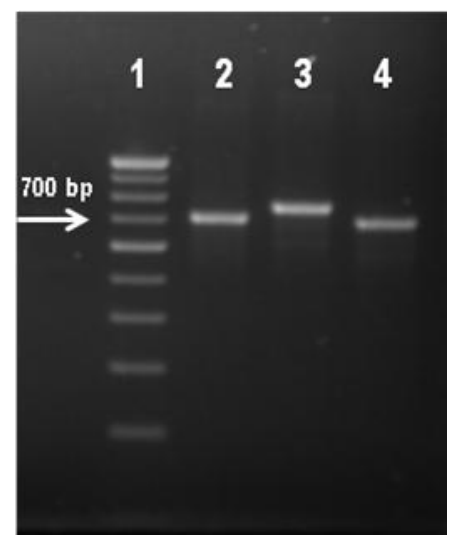

The identification of isolates at genus and species level using molecular markers for genetic differentiation would be an ideal approach.The amplification of rDNA-ITS region by ITS1/ITS4 primer pair gave a single product of approximately 700bp for all three isolates (Fig. 3). The positive clones carrying insert (rDNA-ITS) in the pTZ57R/T vector were confirmed by restriction digestion of plasmids with BamHI and XbaI, which released products approximately of $700 \mathrm{bp}$ size. The nucleotide sequence data (ITS 5.8SrDNA region) for isolates were deposited in NCBI database; accession numbers are given in Table 4. In current study, the isolates RS1 and RS4 were $98 \%$ and $99 \%$ homologous to $R$. solani AG4-HIII and $R$. solani AG1-IA respectively; while RS3 showed $89 \%$ and 94 $\%$ identity with $S$. hydrophilum and $R$. solani respectively. During ITS region analysis, $\mathrm{Xu}$ et al., (2010) found $S$. hydrophilium grouped with T. cucumeris with $95 \%$ bootstrap support and with Rhizoctonia sp. with $78 \%$ bootstrap support. This confirms similarity between $S$. hydrophilum and $R$. solani at molecular level as well; as was found in our study.

Morphologically different $R$. solani isolates with varying degree of virulence were purified from same rice genotype cultivated at different locations in current study. Further study with more isolates is required for better understanding of this fungal population.

\section{References}

Altschul, S.F., Gish, W., Miller, W., Myers, E.W. and Lipman, D.J. 1990. Basic local alignment search tool. Journal of Molecular Biology. 215(3): 403-410.

Bintang, A.S., Wibowo, A., Priyatmojo, A. and Subandiyah, S. 2017. Morphological and molecular characterization of Rhizoctonia solani isolates from two different rice varieties. Journal Perlindungan Tanaman Indonesia. 21: 72-79.

Goswami, S.K., Singh, V. and Kashyap, P.L. 2017. Population genetic structure of Rhizoctonia solani AG1IA from rice field in North India. Phytoparasitica. 45: 299-316.

Guleria, S., Aggarwal, R., Thind, T.S. and Sharma, T.R. 2007. Morphological and pathological variability in rice isolates of Rhizoctonia solani and molecular analysis of their genetic variability. Journal of Phytopathology. 155: 654661.

Hall, T.A. 1999. BioEdit: a user-friendly 
biological sequence alignment editor and analysis program for Windows 95/98/NT. Nucleic acids symposium series. 41: 95-98.

Jia, Y., Liu, G., Park, D.S. and Yang, Y. 2013. Inoculation and scoring methods for rice sheath blight disease. Methods in Molecular Biology. 956: 257-268.

Kimiharu, I., Qingyuan, Q. and Masao, A. 2004. Overwintering of rice sclerotial disease fungi, Rhizoctonia and Sclerotium spp. in paddy fields in Japan. Plant Pathology Journal. 3: 81-87.

Kumar, M., Singh, V., Singh, N. and Vikram, P. 2008. Morphological and virulence characterization of Rhizoctonia solani causing sheath blight of rice. Environmental and Ecology. 26: 11581166.

Lal, M., Singh, V., Kandhari, J., Sharma, P., Kumar, V. et al, 2014. Diversity analysis of Rhizoctonia solani causing sheath blight of rice in India. African Journal of Biotechnology. 13: 45944605.

Linde, C.C., Zala, M., Paulraj, R.D., McDonald, B.A. and Gnanamanickam, S.S. 2005. Population structure of the rice sheath blight pathogen Rhizoctonia solani AG-1 IA from India. European Journal of Plant Pathology. 112: 113 121.

Mohanty, S. and Yamano, T. 2017. Rice food security in India: Emerging challenges and opportunities In: The Future rice strategy for India (Eds.) Mohanty, S., Chengappa, P. G., Mruthyunjaya, Ladha, J. K., Baruah, S. et al, Academic Press, Cambridge. pp 1-13.

Mordue, J.E.M., Currah, R.S. \& Bridge, P. D. 1989. An integrated approach to Rhizoctonia taxonomy: cultural, biochemical, and numerical techniques. Mycological Research. 92: 78-90.

Neeraja, C.N., Shenoy, V.V., Reddy, C.S. and Sarma, N.P. 2002. Isozyme polymorphism and virulence of Indian isolates of the rice sheath blight fungus. Mycopathologia. 156: 101-108.

Ramos-Molina, L.M. and Chavarro-Mesa, E. 2016. Rhizoctonia solani AG-1 IA infects both rice and signal grass in the Colombian Llanos. Pesquisa Agropecuária Tropical. 46: 65-71.

Sambrook, J. and Russell, D.W. 2001. Molecular cloning - a laboratory manual. Cold Spring Harbour Laboratory Press, New York.

Sharma, N.R., Teng, P.S. and Olivares, P.M. 1990. Comparison of assessment methods for rice sheath blight disease. Philippines Phytopathology. 26: 20-24.

Singh, R., Murti, S., Tomer, A. and Prasad, D. 2015. Virulence diversity in Rhizoctonia solani causing sheath blight in rice pathogenicity. Journal of Plant Pathology and Microbiology. 6: doi:10.4172/2157-7471.1000296.

Singh, V., Amaradasa, B.S., Karjagi, C.G., Lakshman, D.K., Hooda, K.S. et al, 2018. Morphological and molecular variability among Indian isolates of Rhizoctonia solani causing banded leaf and sheath blight in maize. European Journal of Plant Pathology. 152: 45-60.

Susheela, K. 2012. Characterization, virulence and genetic variation of Rhizoctonia solani AG-1 IA in India. Indian Journal of Plant Protection. 40: 318-328.

Susheela, K. and Reddy, C.S. 2013. Variability in Rhizoctonia solani (AG1IA) isolates causing sheath blight of rice in India. Indian Phytopathology. 66: 341-350.

Taheri, P., Gnanamanickam, S. and Höfte, M. 2007. Characterization, genetic structure, and pathogenicity of Rhizoctonia spp. associated with rice sheath diseases in India. Phytopathology. 97: 373-383.

Tredway, L.P. and Burpee, L.L. 2001. 
Rhizoctonia diseases of turfgrass. The Plant Health Instructor: doi:10.1094/PHI-I-2001-1109-01.

USCB. 2015. United State Census Bureau. http://www.census.gov/population/ international/data/idb/informationGatew ay.php

White, T. J., Bruns, T., Lee, S. J. W. T. and Taylor, J. L., 1990, Amplification and direct sequencing of fungal ribosomal RNA genes for phylogenetics. In $P C R$ Protocols: A Guide to Methods and Applications, Ed. Innis, M. A., Gelfand, D. H., Sninsky J. J. and White, T. J., Academic Press, London, pp. 315-322.

Woperies, M.C.S., Defoer, T., Idinoba, P., Diack, S. and Dugue, M.J. 2009. Curriculum for participatory learning and action research (PLAR) for integrated rice management (IRM) in inland valleys of Sub-Saharan Africa. Technical Manual: 105-109.

$\mathrm{Xu}, \mathrm{Z}$., Harrington, T.C., Gleason, M.L. and Batzer, J.C. 2010. Phylogenetic placement of plant pathogenic Sclerotium species among teleomorph genera. Mycologia. 102: 337-346.

Yugander, A., Ladhalakshmi, D., Prakasham, V., Mangrauthia, S.K., Prasad, M.S. et al, 2015. Pathogenic and genetic variation among the isolates of Rhizoctonia solani (AG 1-IA), the rice sheath blight pathogen. Journal of Phytopathology. 163: 465-474.

\section{How to cite this article:}

Suryawanshi Padmaja Pralhad, P.U. Krishnaraj and Prashanthi, S.K. 2019. Morphological and Molecular Characterization of Rhizoctonia solani causing Sheath Blight in Rice. Int.J.Curr.Microbiol.App.Sci. 8(01): 1714-1721. doi: https://doi.org/10.20546/ijcmas.2019.801.182 